\title{
Political Feasibility of Enhancing India's Midcentury Target for Emissions Intensity
}

Aljawhara Al Quayid, Nourah Alhosain, Yagyavalk Bhatt, Paul Mollet 


\section{About KAPSARC}

The King Abdullah Petroleum Studies and Research Center (KAPSARC) is a non-profit global institution dedicated to independent research into energy economics, policy, technology and the environment across all types of energy. KAPSARC's mandate is to advance the understanding of energy challenges and opportunities facing the world today and tomorrow, through unbiased, independent, and high-caliber research for the benefit of society. KAPSARC is located in Riyadh, Saudi Arabia.

\section{Legal Notice}

(C) Copyright 2019 King Abdullah Petroleum Studies and Research Center ("KAPSARC"). This Document (and any information, data or materials contained therein) (the "Document") shall not be used without the proper attribution to KAPSARC. The Document shall not be reproduced, in whole or in part, without the written permission of KAPSARC. KAPSARC makes no warranty, representation or undertaking whether expressed or implied, nor does it assume any legal liability, whether direct or indirect, or responsibility for the accuracy, completeness, or usefulness of any information that contain in the Document. Nothing in the Document constitutes or shall be implied to constitute advice, recommendation or option. 


\section{Key Points}

ndia's greenhouse gas emissions have grown along with its rapid economic growth, making it the world's third-largest emitter after China and the United States. Under the Paris Agreement, India has committed to

reduce its emissions intensity relative to its GDP by $33-35 \%$ by 2030 , compared with its 2005 level. In this study, we assess the evolving political will to enhance India's stated commitment to combat climate change. We use the KAPSARC Toolkit for Behavioral Analysis (KTAB) to simulate the collective decision-making process among Indian policymakers and to analyze the political feasibility of enhancing India's midcentury targets for its emissions intensity. Key findings from this study are as follows:

India's efforts to fulfill and enhance its climate pledges must balance its need to reduce pollution and combat climate change against its desire to maintain its rapid economic growth.

The Prime Minister's Council on Climate Change leads the formulation of India's emissions targets under the Paris Agreement and climate change discussions more generally. The prime minister advocates for a more aggressive midcentury target than most of the government, to show that India is ambitious about combatting climate change.

Energy companies, the coal sector and related ministries adopt a more conservative position with respect to enhancing India's climate change targets.

Indian stakeholders broadly agree that the country needs to increase its midcentury emissions intensity target to between roughly $40-65 \%$.

Because of their technical capabilities and proximity to decision-makers, think tanks play a significant role in setting India's nationally determined contribution (NDC) targets. Most think tanks are currently more conservative than the political actors, advocating an emissions intensity reduction target of between $46-49 \%$.

Over time, the majority of actors, led by the prime minister, are expected to support an emissions intensity reduction target of around $50-55 \%$. 
n 2015, at the historic 21st session of the Conference of Parties (COP21) in Paris, parties to the United Nations Framework Convention on Climate Change (UNFCCC) reached an agreement to reinforce the global response to climate change. They established a global action plan aimed at keeping the global temperature increase to well below 2 degrees Celsius $(\mathrm{C})$ above pre-industrial levels and to limit this increase to $1.5 \mathrm{C}$. The Paris Agreement obligates all parties to communicate their best efforts through nationally determined contributions (NDCs), pursue national mitigation and adaption measures to achieve their NDC objectives, and strengthen those objectives in the years ahead. India ratified its NDC in October 2016 with three main targets: achieving $40 \%$ of its power capacity from non-fossil fuel sources, reducing its emissions intensity relative to its gross domestic product (GDP) by $33-35 \%$ below 2005 levels by 2030 , and creating an additional 'carbon sink' of 2.5-3 billion tonnes of carbon dioxide equivalent (CO2e) by 2030.

In this study, we focus on the evolving political will of actors toward enhancing the emissions intensity target for 2050 (i.e., the midcentury target). We use the KAPSARC Toolkit for Behavioral Analysis (KTAB), a model of collective decision-making processes (CDMPs), to analyze how the positions of Indian stakeholders will change over time with respect to India's emissions intensity reduction target. KTAB provides a simulation of the evolution of political support in India, based on data gathered from semi-structured interviews conducted in May 2018 in New Delhi with subject matter experts familiar with the Indian political discourse on this topic.

The data gathered from the subject matter experts indicate that the majority of actors that can influence India's midcentury emissions reduction target, directly or indirectly, currently support targets ranging from $40-65 \%$. The coal industry (e.g., Coal India and coal public sector undertakings [PSUs]), the energy industry and several energy-related ministries currently advocate for targets ranging from $43-45 \%$. Conversely, two actors, the state of Gujarat and the Centre for Science and Environment (CSE), advocate the most ambitious targets, ranging from $60-62 \%$.

India's Prime Minister (PM) Narendra Modi is the most influential actor within the decision-making process, and his active engagement in the climate change debate is driving the outcome. While the experts opined that he would support a midcentury target of 55\% (more ambitious than most government actors), the KTAB simulation indicates he is willing to compromise slightly in order to build political consensus. As a result, the simulation indicates that a consensus is likely to form in which the majority of actors are likely to support this target over time. However, two actors stand out as outliers: the CSE continues to push for a much more ambitious target of $62 \%$, and Coal India is expected to maintain its support for a $43 \%$ reduction target.

During interviews with subject matter experts, many emphasized that decisions regarding the formulation of India's NDC occur in a centralized process focused around the PM's Council on Climate Change. Through a sensitivity analysis, we found that the outcome is the same regardless of whether we assume that the decision is made within a small circle, or if decision-makers informally recognize the views of actors in the broader political environment in India in the process of making their decision. Among the Council members, the Minister of Urban Development, as well as non-government members within the Council, are instrumental in slightly lowering the PM's level of ambition. 


\section{Introduction}

D uring 2015's 21st session of the Conference of Parties (COP21) in Paris, countries party to the United Nations Framework Convention on Climate Change (UNFCCC) agreed on a structure where they would commit to 'contributions' toward a global climate agreement. These commitments, Intended Nationally Determined Contributions (INDCs), were the foundation of post-2020 climate action. Once ratified, the INDCs became Nationally Determined Contributions (NDCs). The Paris Agreement aims to hold the increase in the global average temperature to well below 2 degrees Celsius (C) above pre-industrial levels and limit this increase to $1.5 \mathrm{C}$. Further, the Paris Agreement invited countries to develop midcentury, long-term low greenhouse gas (GHG) development strategies.

This paper uses the KAPSARC Toolkit for Behavioral Analysis (KTAB) to conduct a stakeholder analysis of the politics of India's evolving commitment toward the development of midcentury GHG targets. This paper explores the political feasibility of India enhancing its midcentury emissions intensity target within the framework of its NDC. KTAB produces a simulation of actors' evolving advocacy in this political debate using a model of collective decision-making processes (CDMPs).

India holds a unique position within the UNFCCC's climate change discussions. It is an emerging economy with high poverty rates, and a large and fast-growing population that consequently produces low levels of per capita emissions but a high level of emissions in aggregate. The country is very sensitive to the short-term threat of emissions posed by pollution, and it is conscious of the long-term threats associated with climate change. However, because of the limited resources India has to address the issue, climate policymaking remains a complex issue for the country.

In recent years, the Indian government has tried to develop policies that will address climate change. It released its first National Action Plan on Climate Change (NAPCC) in 2008, announcing eight key measures on energy efficiency and renewable energy. Its eight subsidiary missions have been approved, and their implementation has started. Several states have also embarked on processes to formulate state climate plans.

In 2009, at the 15th session of the Conference of Parties (COP15) in Copenhagen, India released a long-term 'nationally appropriate mitigation action' plan to reduce the emissions intensity of its gross domestic product (GDP) between $20-25 \%$ by 2020 , compared with its 2005 level. Later, at COP21, India revised this target and announced its intention to reduce the emissions intensity of its GDP by $33-35 \%$ by 2030 , compared with its 2005 level. The NDC announced at COP21 also includes a commitment to achieve $40 \%$ of its cumulative electric power installed capacity from non-fossil fuel-based energy sources by 2030 . To mitigate its carbon footprint, India also plans to increase forest and tree cover to create an additional carbon sink of 2.5-3 billion tonnes of carbon dioxide equivalent (CO2e) by 2030. The INDC was ratified on October 2, 2016, becoming India's first nationally determined contribution (NDC) under the Paris Agreement. India is strengthening its comprehensive approach, based on the NAPCC, through its key missions on energy efficiency and solar energy (Government of India 2015).

India is the world's third-largest source of GHG emissions after China and the United States, having emitted 2.4 billion tonnes of carbon dioxide (CO2) in 2016. However, on a per capita basis, its CO2 emissions stand at just 1.8 tonnes, well below 
Figure 1. Total CO2 emissions from fuel combustion of the top five emitting countries (1990-2016).

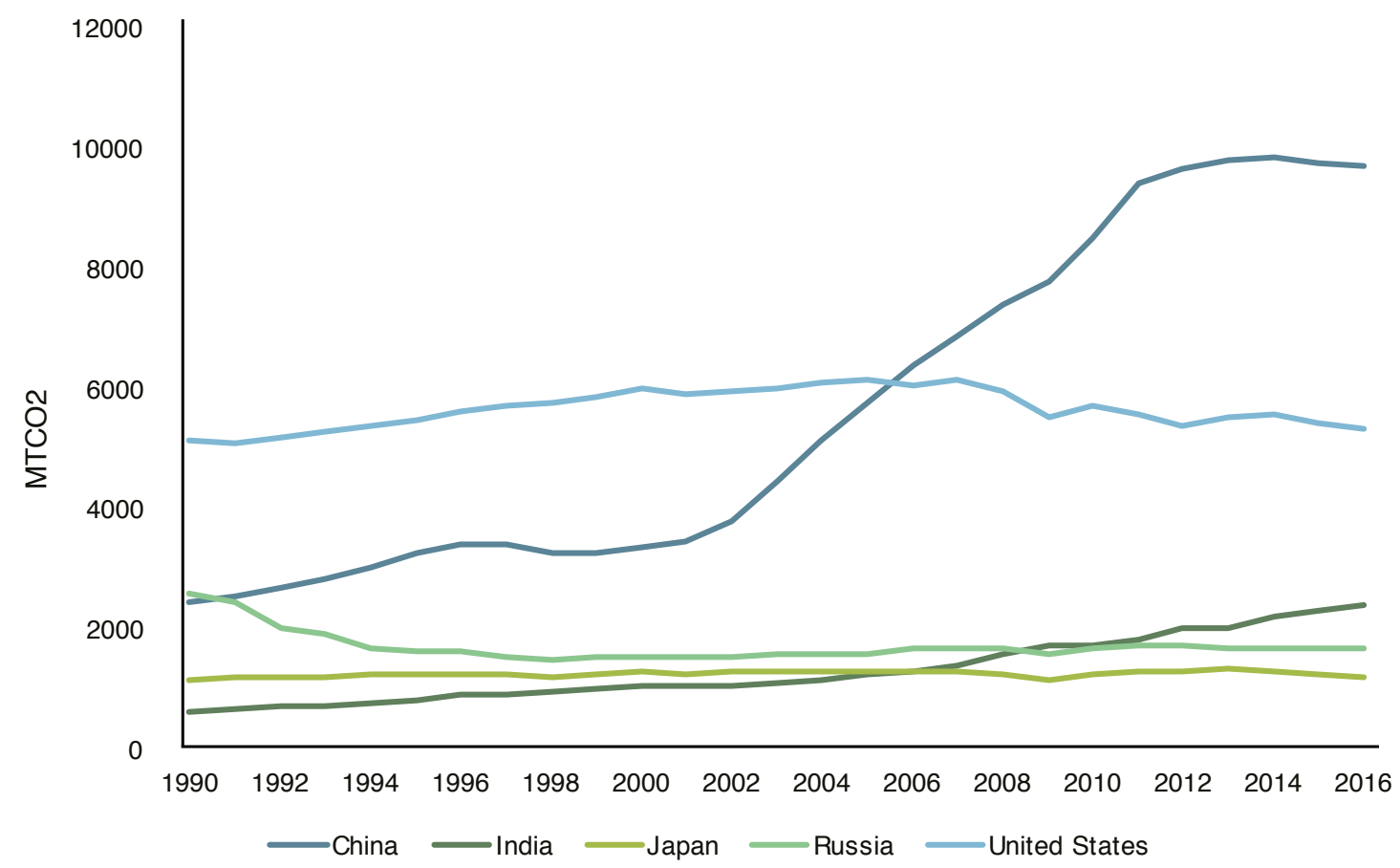

Source: Global Carbon Atlas.

Note: $\mathrm{MTCO} 2$ = Megatonnes of CO2.

Figure 2. CO2 emissions per capita of the top five emitting countries (2016).

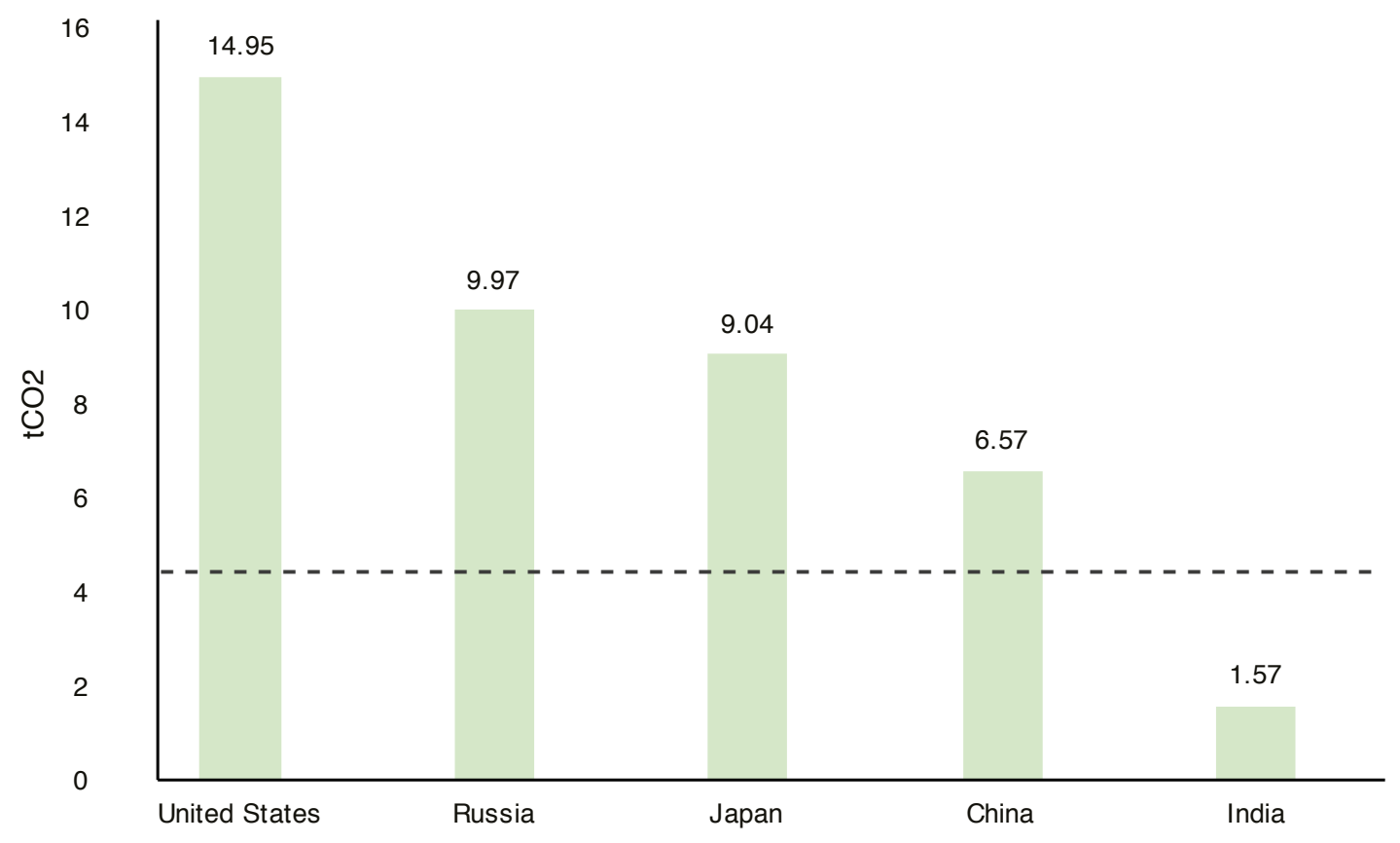

Year 2016

*dashed line indicates world average.

Sources: International Energy Agency (IEA), Energy Atlas.

Note: $\mathrm{tCO} 2=$ total $\mathrm{CO} 2$ 
the world average of 4.2 tonnes (Figures 1 and 2). India's emissions are, of course, driven by its fuel mix, with coal as its primary fuel source. India relies on coal as a cheap source of energy to help increase access to electricity among its population and to maximize economic growth. However, India is also highly vulnerable to the impacts of pollution in the short term and climate change in the long term. Various studies have pointed to the growing frequency and intensity of extreme weather events in India that have the potential for significant adverse impacts on people's livelihoods, especially given that its population is dependent on agriculture and other climate-sensitive sectors. However, the need to provide cheap sources of energy while also combatting climate change creates a significant policy dilemma for the Indian government (Bhatt et al. 2018). 


\section{India's Climate Change Governance Process}

$\mathrm{T}$ The Indian constitution enshrines both features of a federal and unitary system. The executive powers of the central government and of states are clearly defined. Since his election in 2014, Prime Minister Narendra Modi has established a centralized power structure with direct control over many key portfolios, including climate and access to energy. Under the current government, the Prime Minister's Council on Climate Change (PMCCC) was reconstituted to coordinate national action on assessing, adapting to and mitigating against climate change. The PMCCC enables the unambiguous engagement of various scientific entities on the issue of climate change. In the Council, sectoral line ministries and think tanks provide input on matters of climate change and provide general support during discussions before international meetings on climate change (Dubash and Joseph 2015). The ministries under the Council are also tasked to ensure India achieves its NDC targets. The PMCCC is a key government body that provides insights into and helps formulate action plans regarding the assessment of, adaptation to and mitigation against climate change in India.

Figure 3 shows the composition of the reconstituted PMCCC. The prime minister is the chairperson of the Council, with relevant ministries members of the Council. The Council also includes representatives of civil society, mainly officially recognized non-governmental organizations and think tanks. Within the Council, the Ministry of Environment, Forest, and Climate Change (MoEFCC) is the nodal ministry for climate change negotiations. The members of this committee act as advisers to the prime minister, or chairperson. Ultimately, the prime minister is the final authority on all issues relating to climate change policy (Bhatt et al. 2018).

Figure 3. Composition of the Prime Minister's Council on Climate Change (PMCCC).

Prime Minister

\begin{tabular}{l|l|l|l|l|l|l|l|l}
$\begin{array}{l}\text { Minister of External } \\
\text { Affairs }\end{array}$ & Finance Minister & $\begin{array}{l}\text { Minister of } \\
\text { Environment, } \\
\text { Forest and Climate } \\
\text { Change }\end{array}$ & $\begin{array}{l}\text { Minister for Water } \\
\text { Resources }\end{array}$ & $\begin{array}{l}\text { Minister for } \\
\text { Agriculture }\end{array}$ & $\begin{array}{l}\text { Minister for Urban } \\
\text { Development }\end{array}$ \\
\hline $\begin{array}{l}\text { Minister for } \\
\text { Science and } \\
\text { Technology }\end{array}$ & $\begin{array}{l}\text { Minister of State } \\
\text { for Power, Coal } \\
\text { and New and } \\
\text { Renewable Energy }\end{array}$ & Cabinet Secretary & Foreign Secretary & $\begin{array}{l}\text { Secretary, Ministry } \\
\text { of Environment, } \\
\text { Forest and Climate } \\
\text { Change }\end{array}$ & $\begin{array}{l}\text { Non-governmental } \\
\text { members }\end{array}$ &
\end{tabular}

Source: Ministry of Environment, Forest and Climate Change, India. 


\section{KTAB and the Spatial Model of Politics (SMP)}

$7 \mathrm{TAB}$ is a platform that enables the modeling and analysis of CDMPs. CDMPs capture the - political bargaining process, both explicit and implicit, among a set of actors - which can include individuals, institutions, constituencies or identifiable groups or 'blocs.'

This paper presents an analysis of plausible outcomes for CDMPs. We use a specific instantiation of a model in KTAB, based on the Spatial Model of Politics (SMP), one of the most prominent and best-established CDMP models. The SMP simulates how actors interact with and influence one another over time to arrive at a 'feasible outcome' for the modeled question. This reflects a model-based view of the expected outcome for actors' collective support for - or opposition to - enhancing the Indian midcentury emissions intensity target. The experts' aggregate knowledge characterizes the current political landscape (referred to as turn 0), but all simulations beyond turn 0 are based purely on the KTAB SMP calculations.

This paper deliberately focuses on analytic results. For a detailed technical description of the underlying model and its calculations, interested readers are directed to two related KAPSARC papers for more detail:

"An Introduction to the KAPSARC Toolkit for Behavioral Analysis (KTAB) Using OneDimensional Spatial Models" (Wise, Lester, and Efird 2015a).
"Multidimensional Bargaining Using KTAB"

(Wise, Lester, and Efird 2015b).

Both papers are freely available on KAPSARC's website and the KTAB portal, as is the program's source code and documentation. Please visit www. ktab.software for all related papers, the latest version of the software and all materials of interest related to $\mathrm{KTAB}$.

\section{KTAB analysis of the political feasibility of enhancing India's midcentury target}

The first stage of a KTAB analysis is to define the question, i.e., defining the topic in contention among the various actors/stakeholders. As a result, a spectrum of potential actor positions is defined, as shown in Figure 4. This study focuses on stakeholders' positions regarding India's 2050 target to reduce the emissions intensity of its GDP under its NDC. Subject matter experts familiar with India's dynamics regarding this issue were interviewed to obtain information on relevant stakeholders. These semi-structured interviews focused on qualitative information pertaining to the research question, as well as quantitative data for the KTAB simulation. 
Figure 4. Spectrum of actor positions.

What are stakeholders' positions on India's 2050 target to reduce the emissions intensity of its GDP?

\section{Possible targets \\ below the 2030}

target

$0 \%$

$20 \%$
2030 target

Current target

(33-35\%)

$40 \%$
Possible
intermediate $\longrightarrow$

target

$60 \%$
More

ambitious

target

$80 \%$

$100 \%$

\section{KTAB SMP data input}

Data for this study were collected through semistructured interviews with eight subject matter experts in New Delhi in May 2018. Subject matter experts interviewed are affiliated with the following:

Central Ministry, government of India

The Energy Research Institute (TERI)

The Brookings Institution, India

Observer Research Foundation

Center for Policy Research

Council on Energy, Environment and Water

TERI School of Advanced Studies

With the assistance of experts, we identified the key actors involved in the decision-making process, either directly or indirectly, for our specific question. The list includes government entities, officials, states, energy companies, private sector and nongovernmental actors such as think tanks and advocacy organizations. Experts were then asked to assign each actor a numeric value for the following properties:
Position: the location of an actor on the linear spectrum shown in Figure 4. In other words, what is the actors' advocacy with respect to support for/opposition to a more ambitious emissions reduction target in the next framework package?

Influence: the relative degree of political power for each actor. The most powerful actor is assigned a value of 100 , and others are weighted relative to the most powerful actor.

Salience: the relative priority each actor assigns to the new emissions reduction target compared with other issues over which it must exert influence.

After the data collection process, experts' data are aggregated into one dataset, referred to as the baseline dataset, a weighted average of values assigned by experts for each of the three properties needed for a KTAB simulation. Table 1, below, displays the baseline dataset.

Table 1 in Appendix 1 shows the initial expert-based data used in the analysis. It is important to note that in the Indian political structure, one minister can be appointed to handle more than one ministry. Thus, the table may include two or more ministries as one actor. In our analysis, we assume the minister's view would reflect the ministry's position. 


\section{KTAB CDMP simulation results}

With the above data, we can simulate the outcome of the CDMP around the emissions intensity midcentury reduction target in India. The SMP simulates interactions between actors over time in a unit called 'turns,' in which actors iteratively attempt to influence each other based on their evolving perception of how best to achieve their desired outcome.

Figure 5 shows turn 0 of the simulation. The bar graph is a representation of the actors' initial positions based on their average input, depicting the current state of affairs. The location of each bar on the horizontal axis illustrates the actors' positions, while the height of each bar indicates their exercised power: a product of an actor's influence and salience. At first glance, it is apparent that most actors are concentrated around the middle of the spectrum, with no extreme outliers. Actors to the left side of the spectrum include Coal India; coal public sector undertakings (PSUs); the Ministry of Steel (MoS); the Ministry of Agriculture and Farmers' Welfare; the Ministry of Chemicals and Fertilizers; the Ministry of Rural Development; the Ministry of Mines; the Ministry of Heavy Industries and Public Enterprise (MHIPE); and coal, petroleum and chemicals industries. These actors adopt the most conservative positions on India's midcentury emissions intensity reduction target of between $43-45 \%$. Of the actors in this study, they advocate for the least enhancement to the 2030 target.

Figure 5. Initial (turn 0) distribution of actor's positions and effective power.

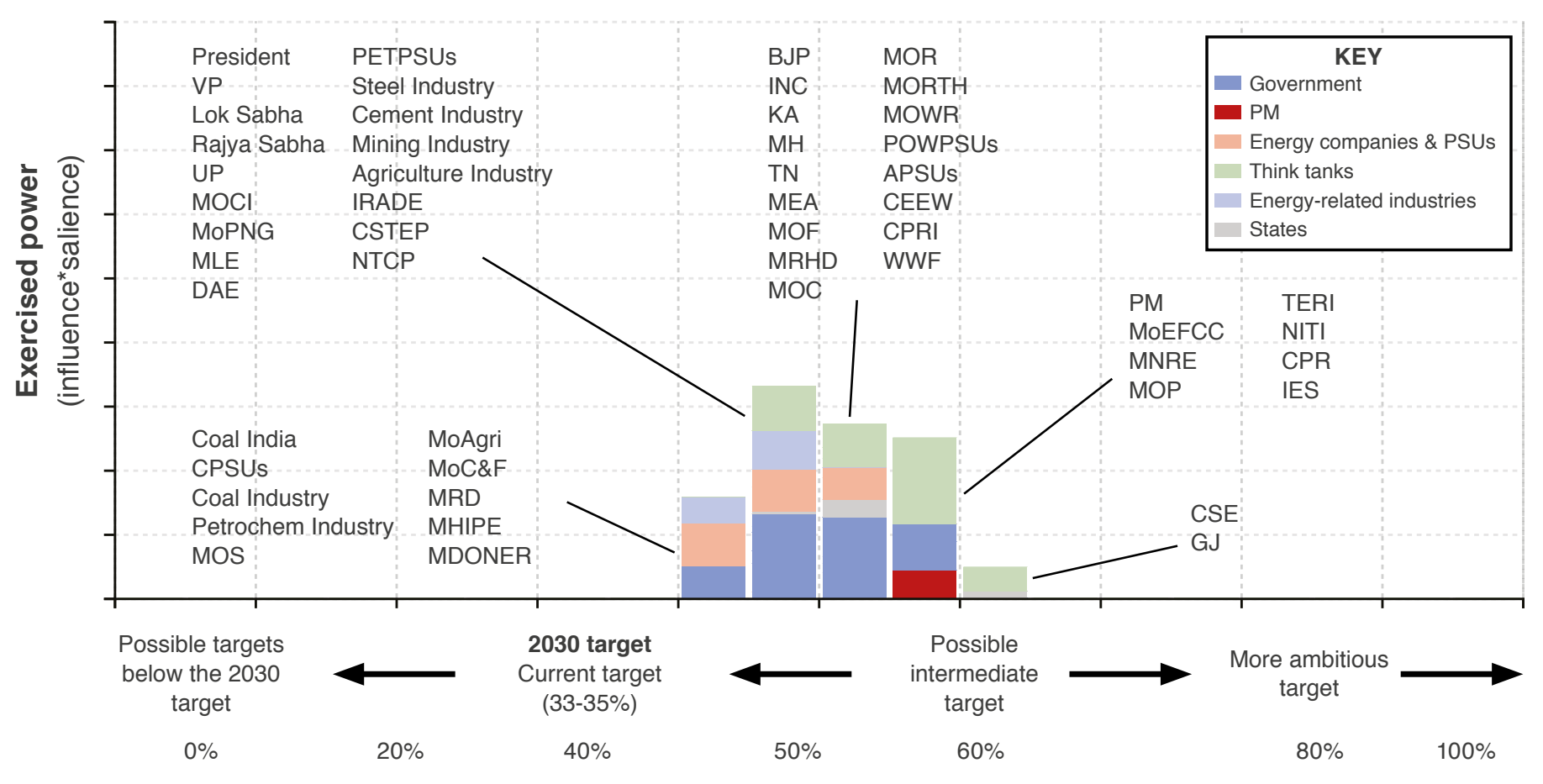

Source: KTAB simulation.

Note: Please refer to Appendix 1 for acronyms. 
On the right side of the spectrum, two actors are slightly more ambitious than many actors among the group. The Centre for Science and Environment (CSE) and the state of Gujarat occupy positions supporting targets around $60-62 \%$. These two actors are known to be the most ambitious on the climate front. Another group of actors that advocate moderately ambitious reductions coalesce around targets ranging from $55-60 \%$. The prime minister (in red) is the most prominent among these actors, along with the Ministry of Environment, Forest and Climate Change, the Ministry of New and Renewable Energy and Ministry of Power, The Energy and Resources Institute (TERI), the National Institution for Transforming India (NITI) Aayog, the Center for Policy Research (CPR) and the Indian
Environmental Society (IES). TERI, NITI and the CPR are all notable think tanks that share the same position, likely because of their engagement with the government as a consultancy group.

The remaining actors form the two clusters in the middle and occupy positions supporting slightly ambitious or slightly conservative targets. The Integrated Research and Action for Development (IRADE) and the Center for Study of Science, Technology and Policy (CSTEP) are two notable think tanks that take a slightly conservative stance. They tend to focus on modeling emissions intensity targets, and as such, their positions may be viewed as support for a realistically achievable target even if it may be less ambitious.

Figure 6. Final (turn 15) distribution of actor positions and effective power.

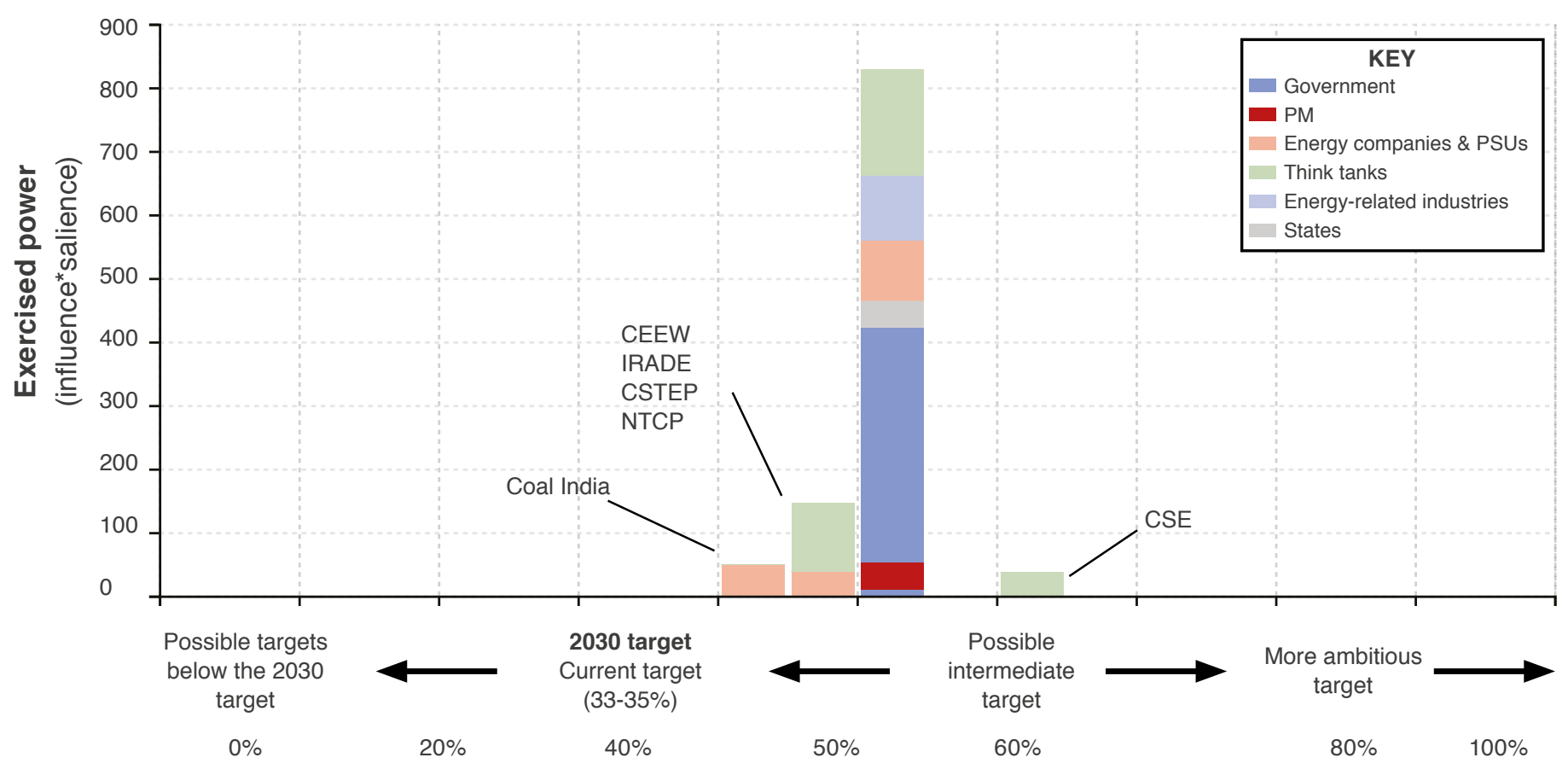

Source: KTAB simulation.

Note: Please refer to Appendix 1 for acronyms. 
The simulation lasted 15 turns, which represents the end of the CDMP as determined by the model. Each turn represents an amount of time, though this is a model construct and not a precise measure. In brief, a 15-turn simulation might represent a year's worth of interactions, at least for the order of magnitude. The final turn is shown in Figure 6. Note that the narrow disagreement among actors has largely disappeared, with the outcome approaching a form of consensus comprising of the majority of actors supporting a target of $52 \%$. However, CSE remains an advocate for a significantly higher emissions intensity reduction target of $62 \%$. On the left side of the spectrum, Coal India remains supportive of the least ambitious target, its initial target of $43 \%$. Think tanks such as IRADE, CSTEP and CEEW support slightly more conservative yet achievable targets ranging from $46-49 \%$, whereas TERI supports a more ambitious target of $57 \%$. While the prime minister initially supported a target of $55 \%$, over the course of the simulation he is persuaded to shift his position to $52 \%$, which is instrumental in forming a consensus around this slightly less ambitious and more feasible target.

Figure 7 shows the simulation results from another perspective, with actors changing their positions over time in response to pressure during the CDMP. The range of advocated positions in India is narrow and narrows further over time, meaning that there is unlikely to be a contentious debate around the 2050 emissions intensity reduction target. Although positions vary initially, most actors join the consensus at around turn 7. As Figure 6 also shows, the only outliers are CSE and Coal India, who are uncompromising and do not shift away from their initial positions. Figures 8, 9, 10, and 11, below, display a breakdown of the various groups and illustrate each group's behavior and interactions during the simulation.

Figure 7. Changing actor positions by turn (all actors displayed).

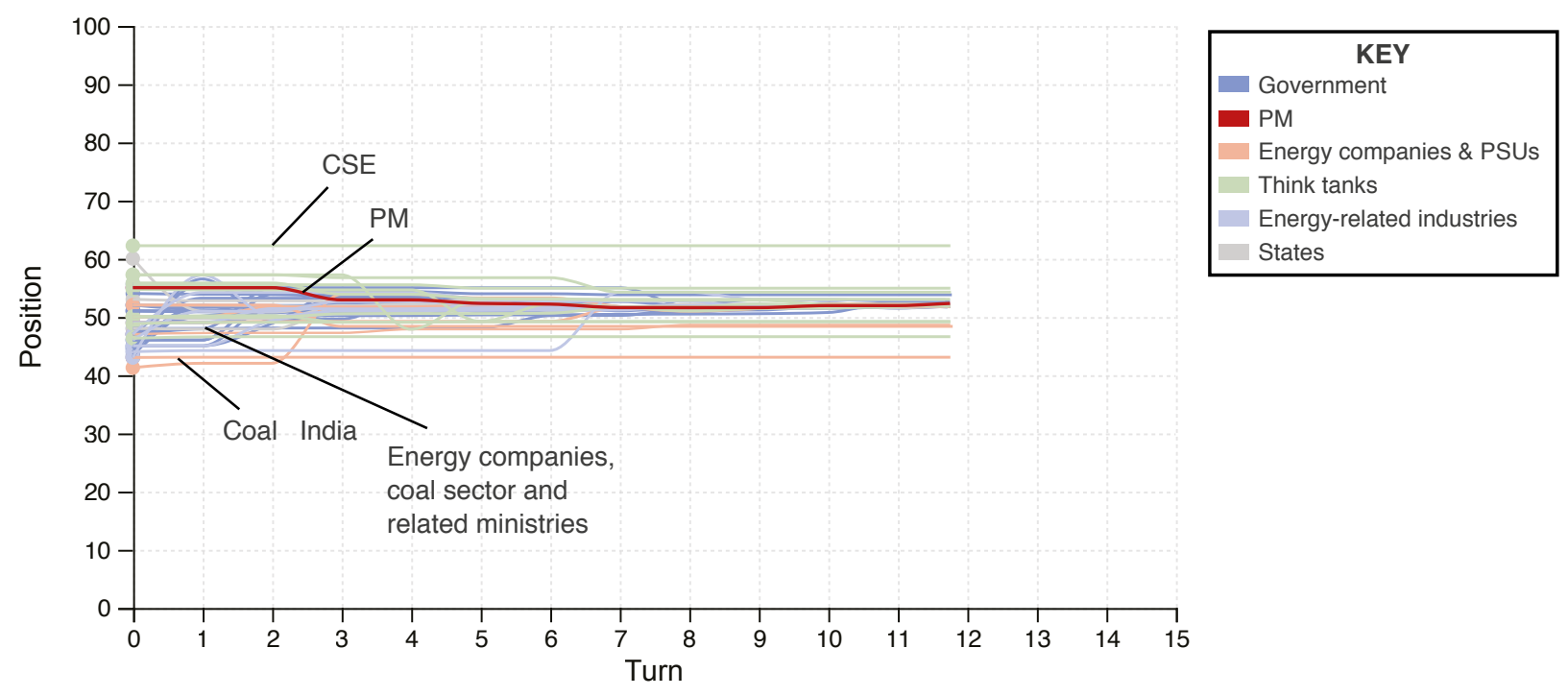

Source: KTAB simulation. 
As seen in Figure 8, the vast majority of ministries and government entities reach consensus at $52 \%$. Although actors in this group start with positions ranging from $43-55 \%$, most see value in joining the consensus following the shift in the prime minister's position from $55 \%$ to $52 \%$. The prime minister's change in position to a slightly less ambitious target could be seen as a sign of the central government's willingness to accommodate differing views and make a consensus more feasible.

Figure 9, above, displays states' behavior throughout the simulation. The five major states in India in terms of population and contribution to GDP play indirect roles in the policy process as the National Action Plan on Climate Change recognizes their roles in its implementation. As a result, all

Figure 8. Changing actor positions by turn (only government actors displayed).

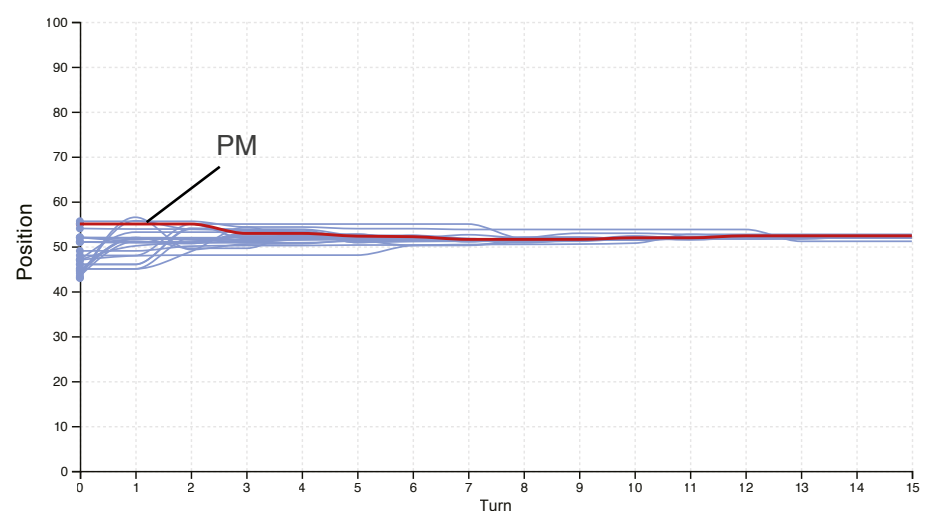

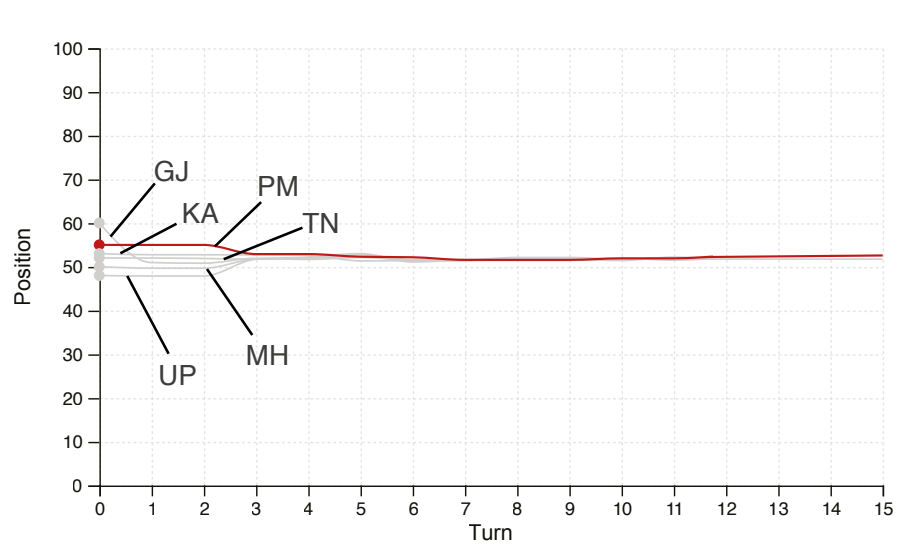

states have formulated their own State Action Plans on Climate Change (SAPCCs) under the provision of the Ministry of Environment, Forest and Climate Change. Moreover, Gujarat is known to be the most progressive state on the climate front and initially supports a highly ambitious midcentury target of a $60 \%$ reduction in emissions intensity. It moves to join the consensus by accepting a proposal from the mining industry. On the other hand, Uttar Pradesh opposes any target above 48\%, making it the least ambitious state. But it also soon joins the consensus by accepting a proposal by Tamil Nadu. Maharashtra, Karnataka and Tamil Nadu initially advocate positions close to the consensus point and do not shift significantly. By the fourth turn of the simulation, all states stand at approximately 52\%, supporting what is ultimately the majority position.

Figure 9. Changing actor positions by turn (only states displayed).

Source: KTAB simulation.

Note: Please refer to Appendix 1 for acronyms. 
Figure 10. Changing actor positions by turn (only energy-related industries and public sector undertakings displayed).

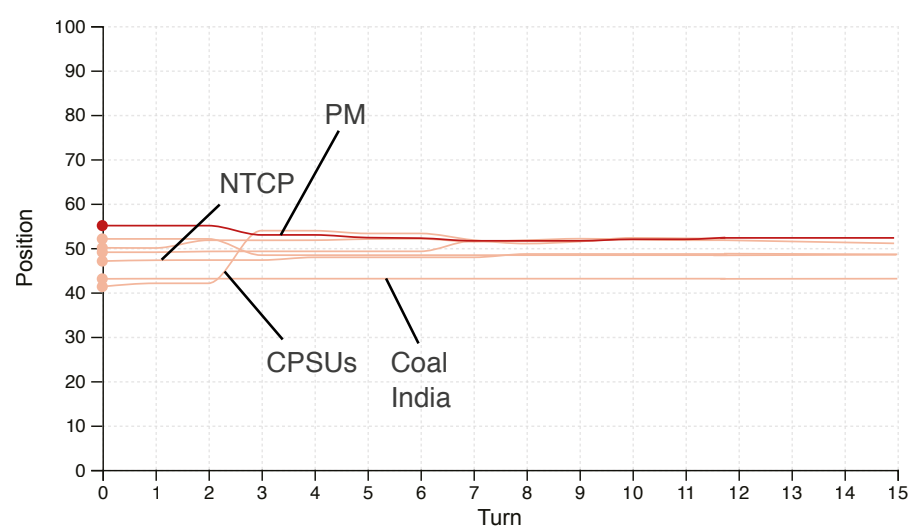

Source: KTAB simulation.

Note: Please refer to Appendix 1 for acronyms.

Figure 10, above, illustrates the behavior of energyrelated industries and PSUs. This group includes the majority of actors opposing ambitious targets, with many initially advocating targets below $50 \%$ and as low as $42 \%$. The Ministry of Coal PSUs show a significant move from their initial position at $42 \%$ to $53 \%$ by accepting a proposal from government-affiliated think tank NITI Aayog. The coal industry is influenced by TERI to join the consensus. This may be due to their modeling of the efficiency of coal-fired power plants.

Mining, steel, petroleum, chemicals, agriculture and cement industries initially oppose any targets above $50 \%$ but soon see value in joining the majority to support a target of $52 \%$. Coal India remains committed to its initial position of $43 \%$ until the final turn and neither offers nor accepts any proposals. This could be because coal power plants provide base load power to the grid, leading Coal India to put more pressure on the coal sector, which may become a significant problem in the near future. Further, Coal India is only a supplier and, even with its complete production capacity today, is in no position to meet demand, leading to rising imports.
Figure 11. Changing actor positions by turn (only think tanks and NGOs displayed).

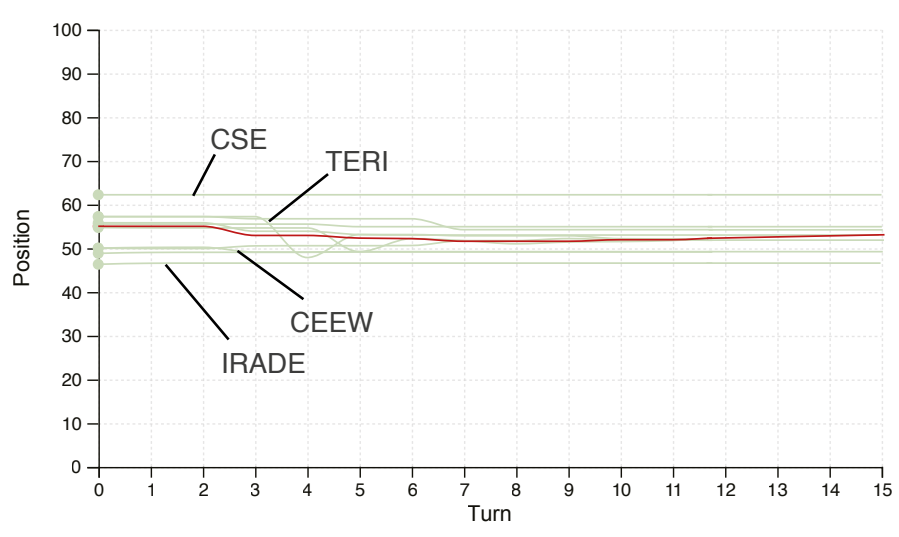

That position is not going to change, as demand will be much higher given the increasing base of coal consuming units.

Figure 11 displays the behavior of think tanks during the simulation. Indian think tanks and nongovernmental organizations play a significant role in climate advocacy and modeling energy intensity targets. Subject matter experts interviewed for this study emphasized the influence of think tanks on climate change-related policy formulation in India. Actors in this group occupy diverse positions ranging from $46-62 \%$. A number of actors stand out among the group, particularly CSE, IRADE and CEEW. CSE supports significantly higher targets, while IRADE and CEEW take a conservative approach by supporting achievable targets. TERI initially supports an ambitious target of $57 \%$, but ultimately joins the consensus toward the end of the simulation. NITI Aayog, the only governmental policy think tank, seems to support the PM's position during the simulation and joins the consensus as soon as it starts to emerge at $52 \%$. Other think tanks initially advocate positions closer to the consensus point and do not shift their views significantly. 


\section{Prime Minister's Council on Climate Change - Sensitivity Analysis}

A s previously mentioned, the Prime Minister's Council on Climate Change was established with the mandate of coordinating national-level action on assessing, adapting to and mitigating against climate change. The Council also helps ensure India achieves the targets set out in its NDC. The prime minister is the chairman and decision-maker of the Council, with 18 members acting as an advisory body on climate change policies.

During interviews for the study, one recurring theme emphasized by subject matter experts was that reaching a decision on the emissions intensity reduction target involves a centralized process, and the decision is often reached in a closed circle. Using KTAB, we can test whether the simulation changes with only this subset of actors in the analysis, ignoring the influence of actors outside the Council. The results of this second simulation allow us to assess whether this assumption makes a difference to the outcome.
The average of the experts' input for this subset of actors can be found in Appendix 1, Table 2. Note that the cabinet secretary and foreign secretary, while members of the Council, were not included as actors, as none of the experts believed they had pronounced views on the issue. As such, they are not expected to try to influence the outcome and can be dropped from the simulation. Values assigned to nongovernmental members include the average of four individuals: Nitin Desai, Chandrasekar Dasgupta, Ajay Mathur and J.M. Mauskar.

Figure 12 shows the initial positions advocated by actors in the Council (turn 0 ). The data remain unchanged from the expert inputs in the first simulation: the prime minister takes a more ambitious view supporting a target of $55 \%$ along with the Minister of MoEFCC, the MNRE and the Minister of Science and Technology. Taking a slightly less aggressive position, the Minister of External Affairs, the Minister of Finance, the Minister of Water Resources and the Minister of Coal support a target of $51 \%$. 
Figure 12. Initial (turn 0 ) actor distribution of actor positions and effective power.

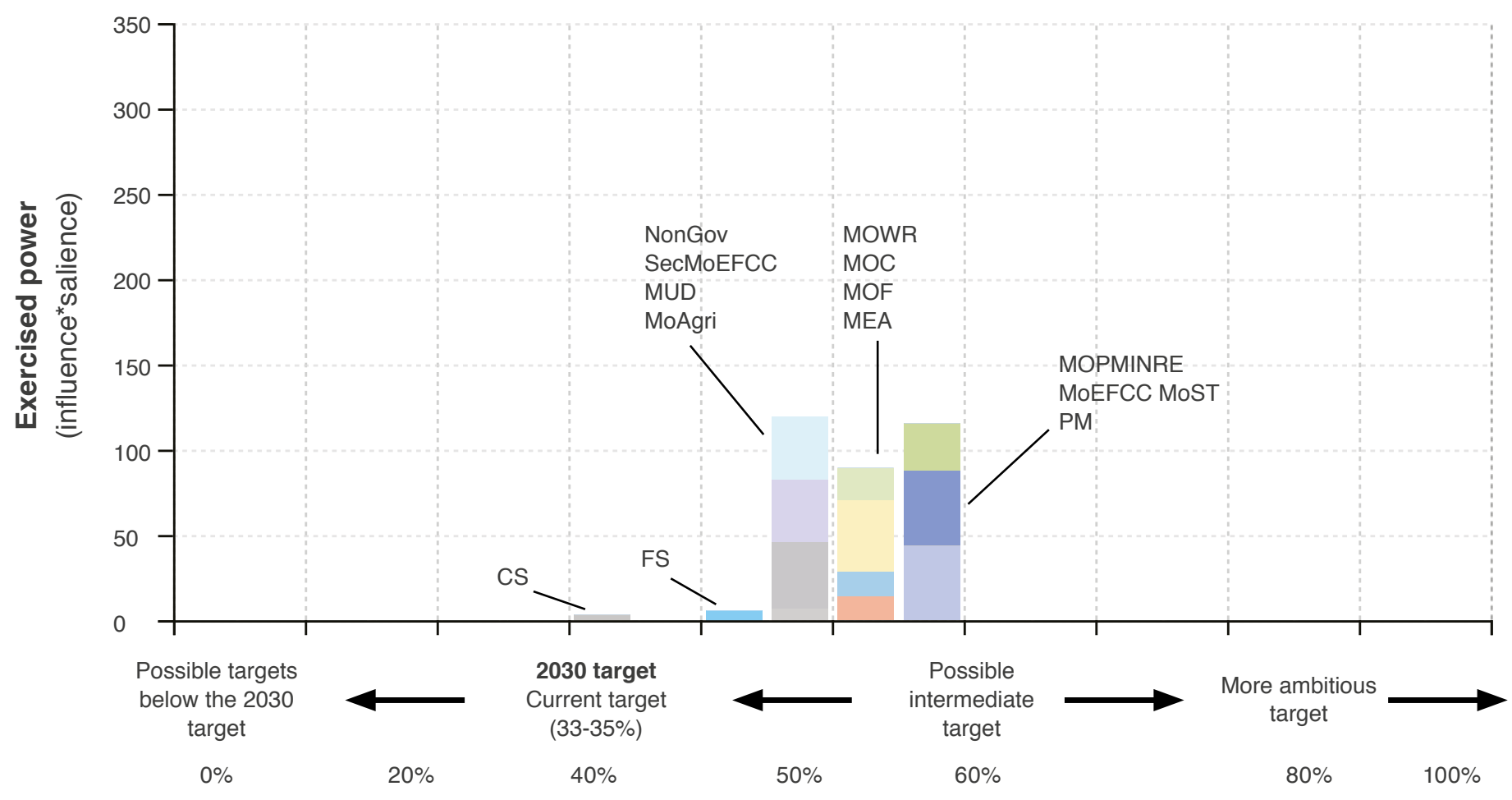

Source: KTAB simulation.

Note: Please refer to Appendix 1 for acronyms.

Actors slightly to the left in this figure, representing support for marginally less ambitious targets, include the Minister of Agriculture and Farmers' Welfare and the secretary of MoEFCC, supporting a target of $45 \%$. The minster of urban development stands at $47 \%$, while nongovernmental members advocate a position of $48 \%$. The foreign and cabinet secretaries initially advocate the least enhancement to the target, at $44 \%$ and $34 \%$, respectively. 
Figure 13. Final (turn 17) distribution of actors' positions and effective power.

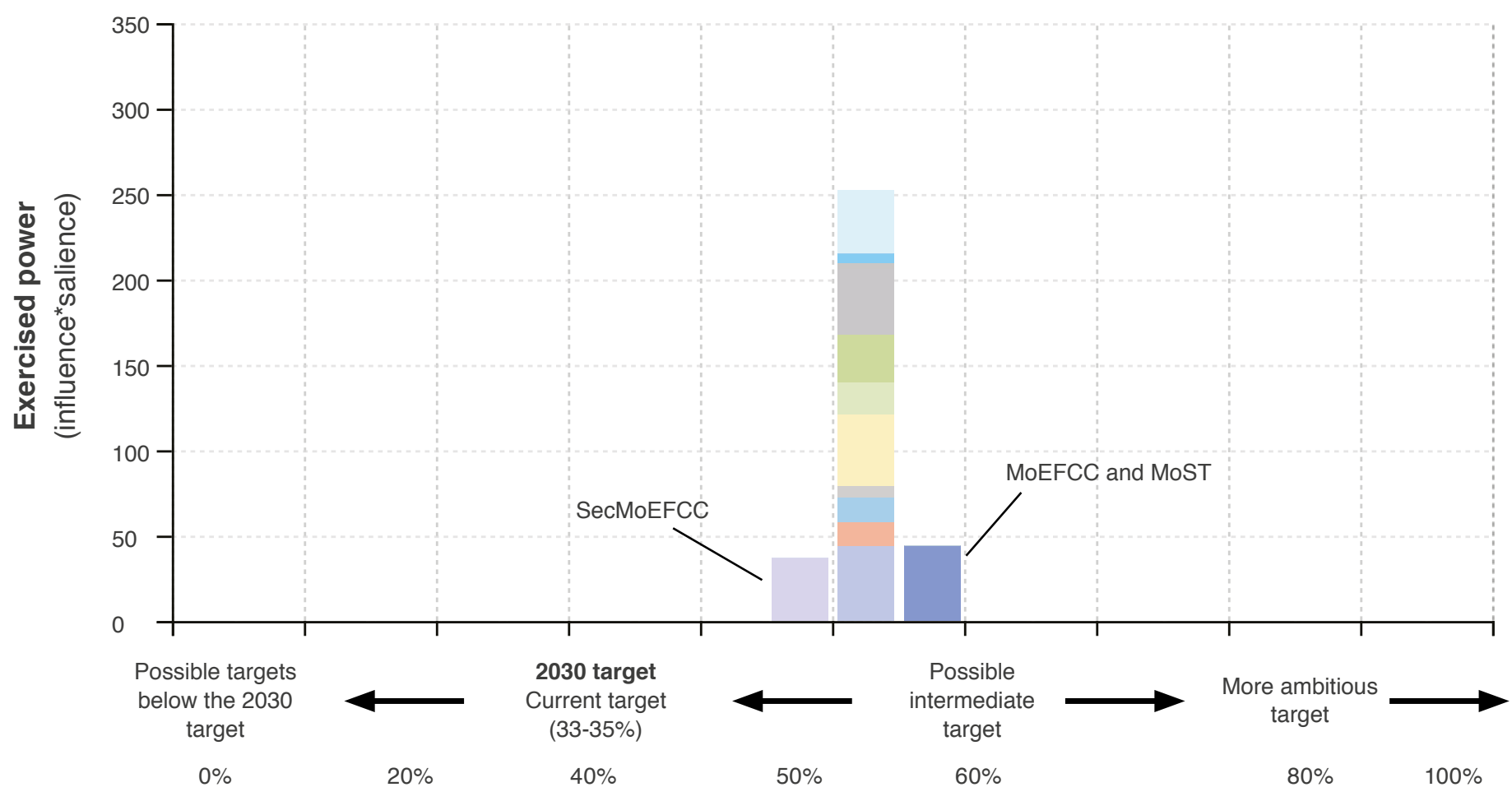

Note: Please refer to Appendix 1 for acronyms.

Source: KTAB simulation.

This simulation ran for 17 turns, which is slightly longer than the original simulation but not meaningfully different. By the final turn of the simulation, shown in Figure 13, most Council members cluster around an emissions intensity reduction target of $52 \%$, the same target reached in the original simulation. The only exceptions are the Minister of MoEFCC and Science and Technology and the secretary of MoEFCC. However, their final positions are not appreciably different than the
PM's, and likely represent just a slight preference for marginally higher or lower targets. Thus, we can infer from this sensitivity analysis that the outcome is likely to remain the same, regardless of whether we assume that the decision on the midcentury target is based on closed-door discussions without any influence from stakeholders in the broader Indian political context, or whether it is a process that informally incorporates the views of actors outside the Council. 


\section{Significant Events Since the Study's Data Collection}

\section{United Nations Climate Change Conference (COP24)}

World leaders and policymakers gathered in December 2018 for the annual United Nations (U.N.) Climate Change Conference (COP24) in Katowice, Poland, the core objective of which was to finalize a rulebook governing the Paris Agreement. The rulebook includes guidelines and procedures that will operationalize nearly all the provisions of the Agreement, including how countries will provide information about mitigation, adaptation, and financial support for climate action in developing countries.

Prime Minister Modi and U.N. Chief Antonio Guterres met before COP24 to discuss the upcoming conference and the importance of completing the Paris Agreement's rulebook. After their meeting, Guterres acknowledged India's support of the Paris Agreement and thanked Modi for his commitment to increase India's NDC. Moreover, the government of India released a document expressing the expected outcomes of COP24. Environment Minister Dr. Harsh Vardhan said, "[The] outcomes of COP24 should be balanced, inclusive, comprehensive and consistent with the principles of [the] UNFCCC, its Kyoto Protocol and Paris Agreement including equity, common but differentiated responsibility and respective capabilities (CBDR-RC), and climate justice." (MoEFCC 2018)

At Katowice, India emphasized its climate change concerns and reaffirmed its Paris Agreement commitments. In addition, the government's statement issued after the Katowice meeting praised COP24's outcomes as positive. However, it noted its reservations on two counts where negotiations failed to meet the country's expectations. First, the Paris Agreement recognized the principle of CBDR-RC, which acknowledges the historical injustice of climate emissions and considers the differentiated capabilities and responsibilities among countries in tackling climate change. During COP24, India was the key country to raise this principle and emphasize the importance of considering equity in the stocktaking process. Given the policy dilemma faced by India regarding the need to reduce emissions yet maintain economic growth and provide cheap energy for its large population, this is a critical consideration. However, developed countries blocked the recognition of this principle in the adopted rulebook. Moreover, developed countries' contributions to climate finance were diluted in the rulebook, exacerbating the challenge of addressing the historical inequity of countries' contributions to global emissions.

The results of the KTAB analysis in this study show significant alignment with India's statement on COP24. The emissions intensity reduction target agreed upon by most actors in the KTAB simulation shows a balanced ambition level that could ensure serious action on the climate front and still maintain space for economic growth while accommodating the country's increasing demand for energy. India's emphasis on CBDR-RC signifies its commitment to both aspects. 


\section{India 2019's General Elections}

ndia's general election was held from mid-April to mid-May, 2019, to elect the members of

parliament who will constitute the Lok Sabha. The Bharatiya Janata Party (BJP) led by Prime Minister Modi has been re-elected for another five-year term. In their campaign manifesto, the BJP emphasized the issue of climate change and the efforts it has been making to tackle the challenges this issue presents (BJP 2019). The BJP's main national opponent, the Indian National Congress (INC) also stated in their manifesto that "climate change has now emerged as a serious challenge for the world community" (INC 2019), and that they are committed to implementing the National Action Plan on Climate Change. Although the BJP won the elections, the prominence both leading parties gave to climate change and the environment in their manifestos shows how critical this issue is becoming to India. 


\section{Conclusion}

he KTAB SMP results provide an insight into the Indian climate debate, particularly the midcentury emissions intensity reduction target. The simulation results indicate that actors participating in the CDMP, either directly or indirectly, are likely to support a midcentury target of approximately $52 \%$. There is a narrow range of views regarding the midcentury target, compared with the domestic political decision-making process of enhancing NDCs in many other countries. Over time, this narrow difference in views is expected to close around a slightly reduced ambition of the Indian prime minister. This simulation result suggests that the prime minister leads the climate conversation in India and that he is willing to make minor concessions to obtain the support of actors pushing for less ambitious emissions targets. Most actors directly involved in the policymaking process reach a consensus on this issue by the end of the simulation. 


\section{References}

Bharatiya Janata Party (BJP). 2019. "Sankalp Patra Lok Sabha 2019." https://timesofindia.indiatimes.com/ realtime/BJP_Election_2019_english.pdf

Bhatt, Yagyavalk, Aljawhara AI Quayid, Nourah Al Hosain, and Paul Mollet. 2018. "India's Balancing Act to Address Climate Change Under the Paris Agreement." KAPSARC Discussion Paper, December. KS-2018-DP46.

Dubash, Navroz, and Neha Joseph. 2015. "The Institutionalisation of Climate Policy in India." Center for Policy Research Working Paper, May.

Government of India. 2015. "India's Intended Nationally Determined Contributions." UNFCCC.

Indian National Congress (INC). 2019 "Congress Will Deliver - Lok Sabha 2019." https://manifesto.inc.in/pdf/ english.pdf

Ministry of Environment, Forest and Climate Change (MoEFCC). 2018. "Union Environment Minister Dr Harsh Vardhan to Lead The Indian Delegation At COP-24." December 1. Press release. http://pib.nic.in/newsite/ PrintRelease. aspx? relid $=186071$
United Nations Framework Convention on Climate Change (UNFCCC). 2015. "India's Intended Nationally Determined Contribution." https://www4.unfccc.int/sites/ submissions/INDC/Published\%20Documents/India/1/ INDIA\%20INDC\%20TO\%20UNFCCC.pdf

- - - 2015. "The Paris Agreement." from https://unfccc. int/sites/default/files/english_paris_agreement.pdf

Wise, Ben, Leo Lester, and Brian Efird. 2015a. "An Introduction to the KAPSARC Toolkit for Behavioral Analysis (KTAB) Using One-Dimensional Spatial Models." KAPSARC Discussion Paper, May. KS-1517-DP011A.

- - - 2015b. "Multidimensional Bargaining Using KTAB." KAPSARC Discussion Paper, November. KS-1524-DP018A. 


\section{Appendix 1. KTAB Input Datasets}

Table 1. Baseline dataset - weighted average of expert inputs.

\begin{tabular}{|c|c|c|c|c|c|c|}
\hline CODE & Actor & Description & Group & Influence & Position & Salience \\
\hline PRES & President & Ram Nath Kovind & Government & 18.4 & 45 & 27.4 \\
\hline VP & Vice President & M. Venkaiah Naidu & Government & 16.4 & 45 & 27.4 \\
\hline PM & Prime Minister & Narendra Modi & Government & 81 & 55 & 54 \\
\hline LOKSAB & $\begin{array}{l}\text { Lok Sabha (House of } \\
\text { People) }\end{array}$ & House of the People & Government & 74 & 47 & 33 \\
\hline RAJSAB & $\begin{array}{l}\text { Rajya Sabha (Council } \\
\text { of States) }\end{array}$ & Council of States & Government & 61 & 47 & 32 \\
\hline BJP & $\begin{array}{l}\text { Bharatiya Janata } \\
\text { Party }\end{array}$ & $\begin{array}{l}\text { Bharatiya Janata } \\
\text { Party }\end{array}$ & Government & 53 & 54 & 31.4 \\
\hline INC & $\begin{array}{l}\text { Indian National } \\
\text { Congress }\end{array}$ & $\begin{array}{l}\text { Indian National } \\
\text { Congress Party }\end{array}$ & Government & 34 & 52 & 27.4 \\
\hline MEA & $\begin{array}{l}\text { Minister of External } \\
\text { Affairs }\end{array}$ & Sushma Swaraj & Government & 49 & 51 & 29 \\
\hline $\mathrm{MOCl}$ & $\begin{array}{l}\text { Minister of Commerce } \\
\text { and Industry }\end{array}$ & Suresh Prabhu & Government & 52 & 49 & 39 \\
\hline MOF & Minister of Finance & Arun Jaitley & Government & 42 & 51 & 34 \\
\hline MoAgri & $\begin{array}{l}\text { Minister of Agriculture } \\
\text { and Farmers, Welfare }\end{array}$ & Radha Mohan Singh & Government & 30 & 44.6 & 23 \\
\hline MHRD & $\begin{array}{l}\text { Minister of } \\
\text { Human Resource } \\
\text { Development }\end{array}$ & Prakash Javadekar & Government & 31 & 52 & 34 \\
\hline $\begin{array}{l}\text { MoEFCC } \\
\text { MoST } \\
\text { MoES }\end{array}$ & $\begin{array}{l}\text { Minister of } \\
\text { Environment, Forest } \\
\text { and Climate Change } \\
\text { Minister of Science } \\
\text { and Technology } \\
\text { Minister of Earth } \\
\text { Sciences }\end{array}$ & Harsh Vardhan & Government & 68 & 55.6 & 65 \\
\hline $\begin{array}{l}\text { MOC } \\
\text { MOR }\end{array}$ & $\begin{array}{l}\text { Minister of Coal } \\
\text { Minister of Railways }\end{array}$ & Piyush Goyal & Government & 70 & 51 & 60 \\
\hline $\begin{array}{l}\text { MORTH } \\
\text { MOWR }\end{array}$ & $\begin{array}{l}\text { Minister of Road } \\
\text { Transport and } \\
\text { Highways Shipping } \\
\text { Minister of Water } \\
\text { Resources, River } \\
\text { Development and } \\
\text { Ganga Rejuvenation }\end{array}$ & Nitin Jairam Gadkari & Government & 48 & 52 & 39 \\
\hline MoPNG & $\begin{array}{l}\text { Minister of Petroleum } \\
\text { and Natural Gas }\end{array}$ & Dharmendra Pradhan & Government & 64 & 47 & 46 \\
\hline MoC\&F & $\begin{array}{l}\text { Minister of Chemicals } \\
\text { and Fertilizers and } \\
\text { Parliamentary Affairs }\end{array}$ & Ananth Kumar & Government & 35 & 43 & 34 \\
\hline MOS & Minister of Steel & $\begin{array}{l}\text { Chaudhary Birender } \\
\text { Singh }\end{array}$ & Government & 39 & 43 & 32 \\
\hline MHIPE & $\begin{array}{l}\text { Minister of Heavy } \\
\text { Industries and Public } \\
\text { Enterprises }\end{array}$ & Anant Geete & Government & 35 & 43.4 & 24 \\
\hline $\begin{array}{l}\text { MRD } \\
\text { MoN }\end{array}$ & $\begin{array}{l}\text { Minister of Rural } \\
\text { Development and } \\
\text { Minister of Mines }\end{array}$ & $\begin{array}{l}\text { Narendra Singh } \\
\text { Tomar }\end{array}$ & Government & 27 & 44 & 24 \\
\hline
\end{tabular}




\begin{tabular}{|c|c|c|c|c|c|c|}
\hline $\begin{array}{l}\text { MOP } \\
\text { MNRE }\end{array}$ & $\begin{array}{l}\text { Minister for } \\
\text { State Power } \\
\text { Minister of New and } \\
\text { Renewable Energy }\end{array}$ & Raj Kumar Singh & Government & 46 & 55 & 60 \\
\hline MLE & $\begin{array}{l}\text { Minister for State } \\
\text { for Labour and } \\
\text { Employment }\end{array}$ & $\begin{array}{l}\text { Santosh Kumar } \\
\text { Gangwar }\end{array}$ & Government & 34 & 46 & 27 \\
\hline MDONER & $\begin{array}{l}\text { Minister for State } \\
\text { Development of North } \\
\text { Eastern Region }\end{array}$ & Dr. Jitendra Singh & Government & 24 & 44.5 & 15 \\
\hline DAE & $\begin{array}{l}\text { Minister for State for } \\
\text { Department of Atomic } \\
\text { Energy }\end{array}$ & Dr. Jitendra Singh & Government & 30 & 48 & 32 \\
\hline MoC\&F2 & $\begin{array}{l}\text { Minister of State } \\
\text { for Chemicals and } \\
\text { Fertilizers }\end{array}$ & Inderjit Singh Rao & Government & 33 & 46 & 27 \\
\hline GJ & Gujarat & $\begin{array}{l}\text { Shri Vijaybhai R. } \\
\text { Rupani }\end{array}$ & States & 27 & 60 & 39 \\
\hline KA & Karnataka & Shri Siddaramaiah & States & 30 & 53 & 38 \\
\hline $\mathrm{MH}$ & Maharashtra & $\begin{array}{l}\text { Shri Devendra } \\
\text { Fadnavis }\end{array}$ & States & 26 & 50 & 35 \\
\hline TN & Tamil Nadu & $\begin{array}{l}\text { Shri Thiru Edappadi } \\
\text { K. Palaniswami }\end{array}$ & States & 20 & 52 & 36 \\
\hline UP & Uttar Pradesh & Shri Yogi Aditya Nath & States & 17.5 & 48 & 26 \\
\hline Coal India & Coal India & & $\begin{array}{l}\text { Energy companies \& } \\
\text { PSU }\end{array}$ & 74 & 43 & 66 \\
\hline NTCP & $\begin{array}{l}\text { National Thermal } \\
\text { Power Corporation }\end{array}$ & & $\begin{array}{l}\text { Energy companies \& } \\
\text { PSU }\end{array}$ & 62 & 47 & 62 \\
\hline POWPSUs & $\begin{array}{l}\text { Ministry of Power } \\
\text { PSUs (Public Sector } \\
\text { Undertakings) }\end{array}$ & $\begin{array}{l}\text { Power Grid, and } \\
\text { National Hydroelectric } \\
\text { Power Corporation } \\
\text { (NHPC) }\end{array}$ & $\begin{array}{l}\text { Energy companies \& } \\
\text { PSU }\end{array}$ & 60 & 52 & 58 \\
\hline PETPSUs & $\begin{array}{l}\text { Ministry of Petroleum } \\
\text { and Natural Gas PSUs }\end{array}$ & $\begin{array}{l}\text { Balmer Lawrie } \\
\text { \& Co. Limited } \\
\text { Bharat Petroleum } \\
\text { Corporation } \\
\text { Limited Biecco } \\
\text { Lawrie Co. Limited } \\
\text { Chennai Petroleum } \\
\text { Corporation } \\
\text { Limited Engineers } \\
\text { India Limited } \\
\text { Gas Authority } \\
\text { of India Limited } \\
\text { Hindustan Petroleum } \\
\text { Corporation } \\
\text { Limited Indian Oil } \\
\text { Corporation Limited } \\
\text { Numaligarh } \\
\text { Refinery Limited } \\
\text { Oil India Limited } \\
\text { Oil \& Natural Gas } \\
\text { Corporation Limited }\end{array}$ & $\begin{array}{l}\text { Energy companies \& } \\
\text { PSU }\end{array}$ & 46 & 49 & 58 \\
\hline
\end{tabular}




\begin{tabular}{|c|c|c|c|c|c|c|}
\hline CPSUs & Ministry of Coal PSUs & $\begin{array}{l}\text { NLC Neyveli Lignite } \\
\text { Corporation }\end{array}$ & $\begin{array}{l}\text { Energy companies \& } \\
\text { PSU }\end{array}$ & 35 & 41.25 & 51 \\
\hline APSUs & $\begin{array}{l}\text { Department of Atomic } \\
\text { Energy PSUs }\end{array}$ & $\begin{array}{l}\text { NPCIL Nuclear } \\
\text { Power Corporation } \\
\text { of India Ltd. } \\
\text { NFC Nuclear Fuel } \\
\text { Complex }\end{array}$ & $\begin{array}{l}\text { Energy companies \& } \\
\text { PSU }\end{array}$ & 36 & 50 & 44 \\
\hline $\begin{array}{l}\text { Petro \& } \\
\text { Chem }\end{array}$ & $\begin{array}{l}\text { Petroleum and } \\
\text { chemicals industry }\end{array}$ & Private sector & $\begin{array}{l}\text { Energy-related } \\
\text { industries }\end{array}$ & 27 & 43 & 41 \\
\hline Coal & Coal industry & Private sector & $\begin{array}{l}\text { Energy-related } \\
\text { industries }\end{array}$ & 47 & 44 & 65 \\
\hline Steel & Steel industry & Private sector & $\begin{array}{l}\text { Energy-related } \\
\text { industries }\end{array}$ & 38 & 47 & 43 \\
\hline Cement & Cement industry & Private sector & $\begin{array}{l}\text { Energy-related } \\
\text { industries }\end{array}$ & 36 & 49 & 43 \\
\hline Mining & Mining industry & Private sector & $\begin{array}{l}\text { Energy-related } \\
\text { industries }\end{array}$ & 34 & 46 & 50 \\
\hline Agri & Agriculture industry & Private sector & $\begin{array}{l}\text { Energy-related } \\
\text { industries }\end{array}$ & 30 & 45 & 38 \\
\hline CPRI & $\begin{array}{l}\text { Central Power } \\
\text { Research Institute }\end{array}$ & & Think tanks & 34.2 & 50 & 39.2 \\
\hline TERI & $\begin{array}{l}\text { The Energy and } \\
\text { Resources Institute }\end{array}$ & & Think tanks & 60.4 & 57.2 & 70.8 \\
\hline $\mathrm{NITI}$ & $\begin{array}{l}\text { National Institution for } \\
\text { Transforming India }\end{array}$ & & Think tanks & 62.1 & 55.8 & 62.5 \\
\hline WFF & World Wide Fund & & Think tanks & 32.8 & 54.7 & 54.2 \\
\hline IES & $\begin{array}{l}\text { Indian Environmental } \\
\text { Society }\end{array}$ & & Think tanks & 35.3 & 57.2 & 59.2 \\
\hline CSE & $\begin{array}{l}\text { Centre for Science } \\
\text { and Environment }\end{array}$ & & Think tanks & 53.3 & 62.2 & 70.8 \\
\hline CPR & $\begin{array}{l}\text { Center for Policy } \\
\text { Research }\end{array}$ & & Think tanks & 49.2 & 55.5 & 65.8 \\
\hline CSTEP & $\begin{array}{l}\text { Center for Study of } \\
\text { Science, Technology } \\
\text { and Policy }\end{array}$ & & Think tanks & 52.5 & 48.8 & 72.5 \\
\hline IRADE & $\begin{array}{l}\text { Integrated Research } \\
\text { and Action for } \\
\text { Development }\end{array}$ & & Think tanks & 46.3 & 46.3 & 70 \\
\hline CEEW & $\begin{array}{l}\text { Council On Energy, } \\
\text { Environment and } \\
\text { Water }\end{array}$ & & Think tanks & 48.8 & 50 & 75 \\
\hline
\end{tabular}

Source: KAPSARC expert interviews. 
Table 2. Scenario dataset - weighted average of expert inputs.

\begin{tabular}{|c|c|c|c|c|}
\hline Actor & Description & Influence & Position & Salience \\
\hline PM & Prime Minister & 81 & 55 & 54 \\
\hline MEA & Minister of External Affairs & 49 & 51 & 29 \\
\hline MOF & Minister of Finance and Corporate Affairs & 42 & 51 & 34 \\
\hline MoAgri & Minister of Agriculture and Farmers, Welfare & 30 & 45 & 23 \\
\hline MoST & Minister of Science and Technology & 68 & 56 & 65 \\
\hline MoEFCC & $\begin{array}{l}\text { Minister of Environment, Forest and Climate } \\
\text { Change }\end{array}$ & 68 & 56 & 65 \\
\hline MOC & Minister of State for Coal & 70 & 51 & 60 \\
\hline MOWR & Minister of Water Resources & 48 & 52 & 39 \\
\hline MOP MNRE & $\begin{array}{l}\text { Minister of State for Power and New and } \\
\text { Renewable Energy }\end{array}$ & 46 & 55 & 60 \\
\hline MUD & Minister of Urban Development & 67 & 47 & 58 \\
\hline CS & Cabinet Secretary & 27 & 34 & 12 \\
\hline FS & Foreign Secretary & 27 & 44 & 22 \\
\hline SecMoEFCC & $\begin{array}{l}\text { Secretary, Ministry of Environment, Forest and } \\
\text { Climate Change }\end{array}$ & 50 & 45 & 73 \\
\hline NonGov & Non-governmental members & 48 & 49 & 76 \\
\hline Minister of Earth Sciences & Nitin Jairam Gadkari & 48 & 52 & 39 \\
\hline Minister of Coal & Dharmendra Pradhan & 64 & 47 & 46 \\
\hline Minister of Railways & Ananth Kumar & 35 & 43 & 34 \\
\hline $\begin{array}{l}\text { Minister of Road Transport and } \\
\text { Highways Shipping }\end{array}$ & Chaudhary Birender Singh & 39 & 43 & 32 \\
\hline $\begin{array}{l}\text { Minister of Water Resources, } \\
\text { River Development and Ganga } \\
\text { Rejuvenation }\end{array}$ & Anant Geete & 35 & 43.4 & 24 \\
\hline $\begin{array}{l}\text { Minister of Petroleum and Natural } \\
\text { Gas }\end{array}$ & Narendra Singh Tomar & 27 & 44 & 24 \\
\hline $\begin{array}{l}\text { Minister of Chemicals and } \\
\text { Fertilizers and Parliamentary Affairs }\end{array}$ & Raj Kumar Singh & 46 & 55 & 60 \\
\hline Minister of Steel & Santosh Kumar Gangwar & 34 & 46 & 27 \\
\hline $\begin{array}{l}\text { Minister of Heavy Industries and } \\
\text { Public Enterprises }\end{array}$ & Dr. Jitendra Singh & 24 & 44.5 & 15 \\
\hline
\end{tabular}

Source: KAPSARC expert interviews. 


\section{About the Authors}

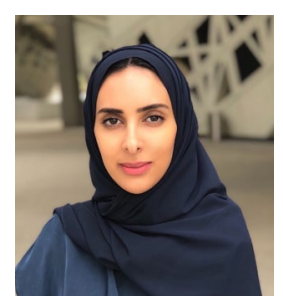

\section{Aljawhara Al Quaid}

Aljawhara is a research analyst in KAPSARC's Policy and Decision Science program with research interests in political economy, international affairs, finance and trade. She is currently working on evaluating the political feasibility of energy, environmental and economic policy options. Aljawhara holds a B.S. degree in business administration with a focus in finance from Alfaisal University.

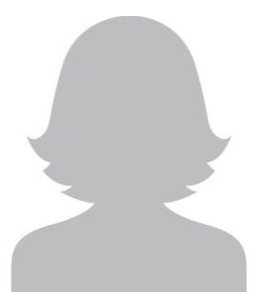

\section{Nourah Al Hosain}

Nourah is a research analyst in KAPSARC's Policy and Decision Science program. Her interests lie in data science and tool development. She is currently working with the KAPSARC Toolkit for Behavioral Analysis development team, and KAPSARC's Geographic Information Systems team.

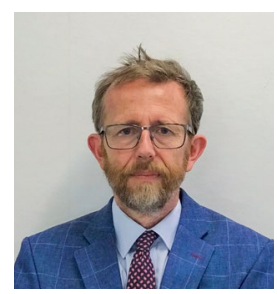

\section{Paul Mollet}

Paul is a research fellow in KAPSARC's Policy and Decision Sciences program. He is an analyst with over 25 years of experience covering international oil and energy markets. Paul has attended numerous OPEC meetings and written extensively about the oil industry in publications such as Platts Oilgram News, Argus Global Markets, and the Petroleum Economist.

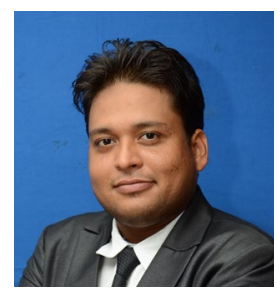

\section{Yagyavalk Bhatt}

Yagyavalk is a senior research analyst at KAPSARC, working on energy policies, with a focus on alternate energy, climate change, and automotive fuels. He previously worked as a researcher, providing sustainable development and decentralized renewable energy system solutions to the rural areas of north India. He holds an M.Tech degree in renewable energy from TERI University.

\section{About the Project}

KAPSARC has developed the KAPSARC Toolkit for Behavioral Analysis (KTAB), an open source software platform, to model and analyze collective decision-making processes (CDMPs). KTAB is intended to be the standard platform for analyzing bargaining problems, generalized voting models and policy decision-making. We intend to use KTAB to assemble the building blocks for a broad class of CDMPs. Typical models in KTAB will draw on the insights of subject matter experts regarding decision-makers and influencers in a methodical and consistent manner, helping researchers to identify feasible outcomes of CDMPs. 
INAPSARC

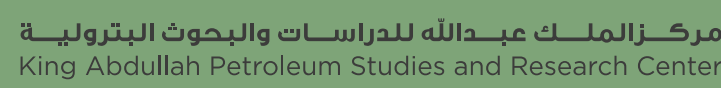

www.kapsarc.org 